\title{
大きい河岸侵食力を有するクランクフローの 基本的事項に関する考察 \\ ASTUDY ON THE BASIS OF CRANK FLOW WHICH HAS POWER TO BIRING BIG BANK EROSION
}

\author{
須 賀 如 川 \\ Nyosen SUGA \\ フェロー員 工博 宇都宮大学名誉教授 河相工学研究堂代表 \\ （干276-0023千葉県八千代市勝田台 4-2-4）
}

\begin{abstract}
Crank flow is a flow pattern which has plain shape of crank, and after development, crank flow becomes to a bank attacking concentrated flow at sharp angle, and brings large scale bank erosion. Practically in many rivers in Japan, the developments of crank flows are recently becoming remarkable and are recognized beyond sufferance in some cases. In this paper, classification of crank flow and main causes of development are discussed using some field data and also field investigation in some rivers. Results of this study are expected to practical application and offer suggestion to further developments of the study.
\end{abstract}

Key Word: crank flow, bank attacking concentrated flow at sharp angle, bank erosion, field data, field investigation

\section{1. クランクフローと研究の意義}

クランクフローとは, 河道内のみおの平面形状が, ク ランク状を呈する流れの形態を総称する. 写真-1 に示す 那賀川の昔のみおの状況は通常の蛇行形態と把えられる が, 3 番目 (1974 年)の写真のみおの状態はクランクフロ 一の典型例とみなすことができる. これは, 而侵食性河岸 の場合, 及び流れを変更しうる堆積がある場合等を除き 自己形成されず,多くは人為作用との係りを有するもの であり,直線的な鋭角水衝流を伴うことに特徵がある.こ の点で一般の曲線的な低水路蛇行流已相違する.

河岸に対する鋭角な水衝流は, 中小出水あるいは大洪 水の減水期等において，予想を超える大規模な河岸侵食 の原因となることがあるが, 従前の本格的な研究は認め られない．そのため, クランクフローは河岸保全の観点 からの意義を有する現象として注視の要があり, 鋭角水 衝流の現象が重要課題となることから, 河道を横断し, 河岸に対して鋭角水衝流となる全ての流れをクランクフ ローに含めて考察対象とする.

クランクフローは, 谷底平野を流下する河川等で古来 より存在していた流れの形態であるが，戦後は急激な河 道条件の変化にともなって散見されるようになり，最近 では低水路内において多数出現しており，実務上の対応 策が苦慮されているようである. 特にクランクフローは, 時間的に急激に発達することがあり，それに従って鋭角
水衝流の威力が急増し, 顕著な河岸侵食が局所的に発生 する事例が多くみられるようになった. 例えば, 表-1 の鬼 怒川(写真-3 の東北新幹線や写真-5 の中島橋)などがこれ に該当する.そのため, クランクフローは現在ではニーズ 面からみて新しい研究課題であるともいえよう.

しかしながら, クランクフローについては, 個別の模 型実験等による検討例は別として，多くは緊急の災害事 例として取扱われてきた. そのため, 研究二ーズの逼迫 性が認識されているにも拘らず，現象の本質に関する調 査·研究が従前には行われていないものと思われる. そこ で本論においては，速竍性を重視する立場から河川にお ける限られた事例調査結果に基づいて, 初の試みとして, クランクフローの分類・クランクフローの発達過程とそ の原因·鋭角水衝流の規模·河岸侵食現象の内容及び対応 策の考え方等の各項目について行った基本的考察結果等 を示すこととし,なかでもクランクフローの形成機構や 変動機構の本質を理解する上での基本となる河岸沿いの みおの発達と延伸の現象について発散・収束河道での実 態例を事例としてとりあげることとするが, 当面の研究 目的は，実務における対応策の基本的な検討に資するこ と及び今後の研究発展の方向性の示唆としている.

\section{2. クランクフローの種類とその原因}

\section{クランクフローと鋭角水衝流の流れの形態は昔から存}




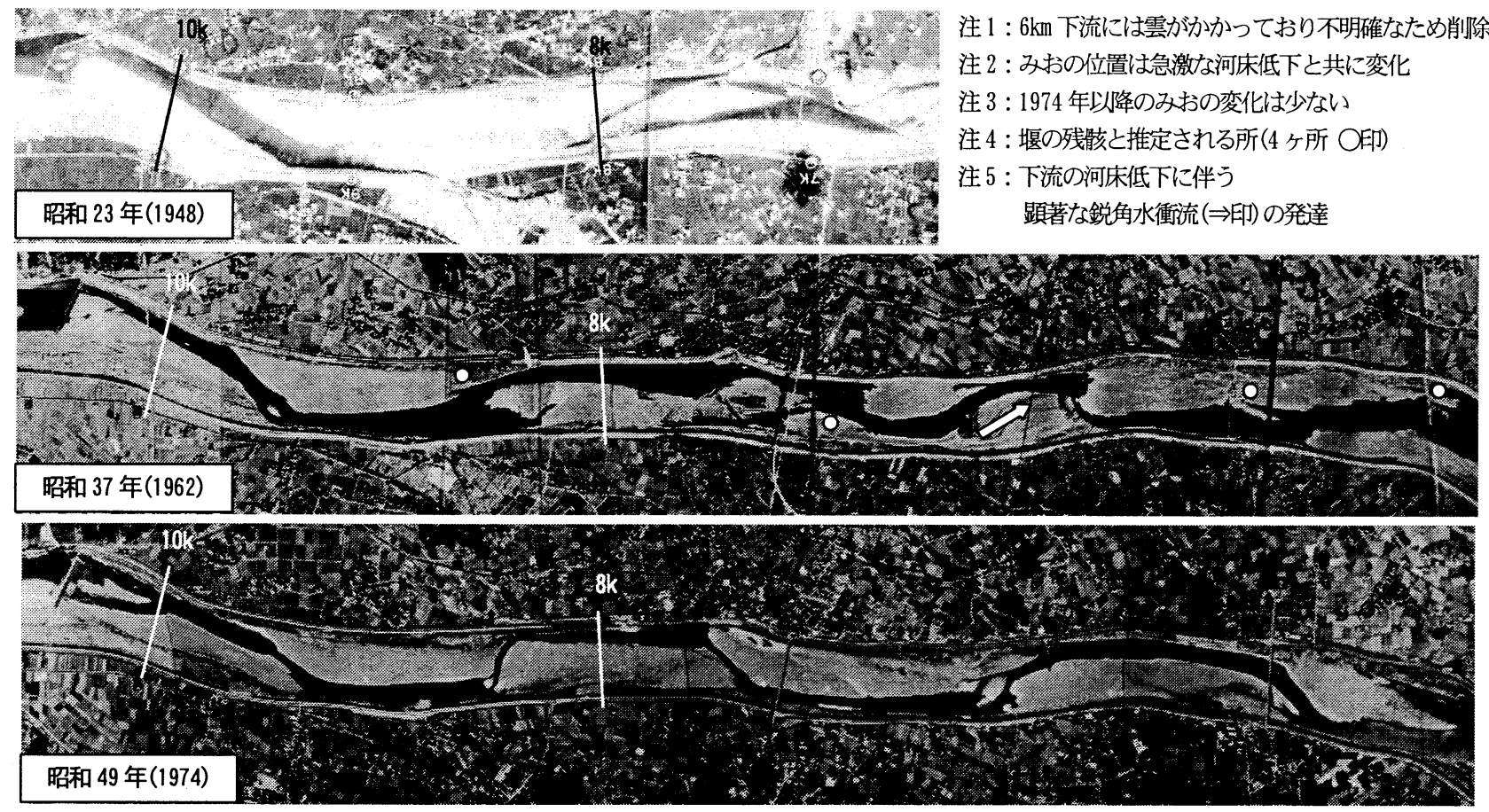

写真-1 那賀川下流部におけるクランクフローへの発達過程

在するものであるが，研究対象として注目されることは なかった. 実務においては, クランクフローによる河岸 侵食が生じた段階で水衝流の強い作用力を認識し, 多く は対処療法的工法を採択して, 旧河川法で定めた工事実 施基本計画における計画断面の維持に努めてきたと思わ れる.一般的に解決すべき重要問題との認識が必要であ る. このような鋭角水衝流には, 表-1 に示すように, 多 数の種類が存在する. この中には, 最近徐々に現象が顕 著になり, 被災事例の増大しているものがある.

那賀川における写真-1 のクランクフローは，昭和 40 年代に発達したものである. 昭和 23 年の航空写真は部分 的に雲のかげで覆われているが，堤防は概成しており， 波長の長い通常の交互砂州が発達していた. 那賀川は洪 水発生頻度の大きい河川であり, 流出土砂量も少なくな いので流路の縦断バランスはよいが,かなりダイナミッ クな河床変動のある河川之位置付けられる. しかし，用

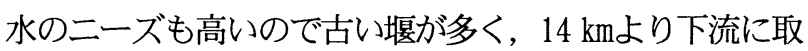
水兼用の 7 基の床止堰(固定堰)があった.これらは，日 中戦時より統廃合が実施にうつされつつあつたが，戦後 のある時期迄荒廃するに任された．低水護岸の老朽も著 しく, 引堤等も行われ，河床低下に拍車をかける一因と もなっていた. 昭和 23 年の航空写真では通常の蛇行河道 であり,昭和 37 年の航空写真には㘿の残䯓と推定される ものが 4 ヶ所みえる. 昭和 37 年と昭和 23 年とを比較す ると蛇行の波長は概ね不変であるが, みおの円滑さが失 われた. 堰の残散はやがて消失し, 昭和 37 年には河岸沿 いの直線的なみおの鮮明化があってクランクフローの発 達が始まり, 昭和 37 年の写真に示す鋭角水衝流はこのあ と $6 \mathrm{~km}$ 下流のクランクフローの発達に関与したものであ り,下流部の河床低下の影響が考えられる. なお，井口 ${ }^{3)}$ によると, 昭和 43 年から昭和 49 年の 6 年間では, $5 \mathrm{~km}$
ら $9 \mathrm{~km}$ 間の 4 つの砂礫堆前緑線はほぼ同じ形をたもつた まま 83mから $155 \mathrm{~m}$ 前進したとの鮏川の調査結果を紹介 しているが,昭和 50 年代以降はほぼ固定したとみなされ る. 現在では当時の資料はなく, 確定的なことは言えない が, 確率現象とは考えられず, 当時他の河川ではこのよう な典型的なクランクフローは見られないことから, 那賀 川におけるクランクフロー形成とその安定化の主因は堰 の流失に伴う急激なみおの河床低下とクランクフローを 発達させる水理条件に基づくものであると推定される.

また，近年多くの河川において砂利採取が制限された 後，急激な河床低下の緩和や河道形態のバランスが緥断 的に回復しつつあるが，一部の河川，特に流送土砂量の 少ない河川においてみおの鮮明化，砂州等における高木 の繁茂や団結化が進行し，クランクフローが顕著になり つつある河道が散見される.この現象で注目されること は，災害復旧による護岸の建設(水制なし)が，次のクラ ンクフローの発達を促進し, 以降の洪水において, 災害 区間の間欠的な延伸が左右岸交互に行われつつあること である. 写真-2 は松浦川の佐里地区 $(18 \mathrm{~km})$ における例で あるが，一般に直線的な護岸はその前面にみおを呼込み， 両岸の護岸は 2 列蛇行を形成しやすくという傾向を有し

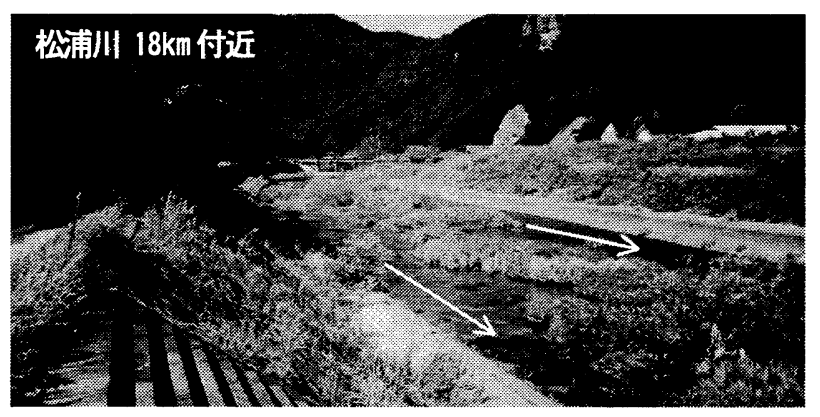

写真-2 松浦川の佐里地区における両岸の護岸と 2 列蛇行流(両岸沿いの流れ) 
表-1 クランクフローの種類と発達の主因

\begin{tabular}{|c|c|c|c|}
\hline NO & $\begin{array}{l}\text { クランクフロー発達の } \\
\text { 原因(直接的なもの) } \\
\end{array}$ & 発達の条件等 & 参考事例 \\
\hline 1 & 護岸設置に伴う河岸沿いのみおの延伸 & カマボコ型河道 (発散域)の2列蛇行, 両岸みおの高低差 & 鬼怒川，渡良瀬川，神通川 \\
\hline 2 & 河床低下 (急激) & 洪水による固定堰の流失と河床低下の波及 & 那賀川 \\
\hline 3 & 河床低下 (供給士砂量の減少等) & \begin{tabular}{|l|} 
みおの鮮明化 \\
交互砂州の伝播速度の維断的不均街 \\
砂州部における高木等による耐侵食性の增大，高水敷の \\
土地利用, 洪水流量の平準化
\end{tabular} & 相模川，多摩川 \\
\hline 4 & 河道掘削 (旧河川法での計画断面の確保) & \begin{tabular}{|l} 
大碟堆等自然の河道システムの破壊 \\
大碟を含む混合粒径特性の変化 \\
\end{tabular} & \begin{tabular}{|l} 
天竜川下流部 \\
信浱川下流部
\end{tabular} \\
\hline 5 & 土砂供給量の急減 & $\begin{array}{l}\text { 大規模砂利採取地区下流における土砂供給量の減少 } \\
\text { (採取地区での堆砂) }\end{array}$ & 鬼怒川(上平地区下流) \\
\hline 6 & 不安定大棵堆の発達 & \begin{tabular}{|l} 
巨石, 碟のジャムアップ \\
扇状地頂部, 土砂量大の支川合流点下流
\end{tabular} & \begin{tabular}{|l|} 
大谷川の派川 \\
マドンガン川の派川
\end{tabular} \\
\hline 7 & $\begin{array}{l}\text { 塸(頭首工等) } \\
\text { 床固 }\end{array}$ & $\begin{array}{l}\text { 端部の相対的強度が低い場合, 林固上流側の河道横断 } \\
\text { 方向流れ }\end{array}$ & $\begin{array}{l}\text { 多摩川(狛江地区), 菊池川 } \\
\text { 濁川(阿武隈川支川) }\end{array}$ \\
\hline 8 & 河床勾配の急変点 & \begin{tabular}{|l} 
土砂量の多い河川 \\
洪水滅水期の砂の堆積·砂州発達之偏流
\end{tabular} & 常願寺川 \\
\hline 9 & 大径碟の減少(採取) & 流路の直線化 & \\
\hline 10 & 河口砂州の発達 & 河口砂州の発達·汀線方向への延伸 & 阿武德川河口 \\
\hline 11 & 谷底平野の山地河川流路の直進性 & 粒径が大きくなく, 勾配が急な場合 & 黑川 344) \\
\hline 12 & 網流河道砂州の伝播速度の相建·不安定性 & \begin{tabular}{|l|} 
小規模な砂州のオーバーテイクによる流路の統合・拡大 \\
網流形態システムの不安定化
\end{tabular} & \begin{tabular}{|l} 
鬼怒川(氏家付近） \\
多摩川(昭和30年代末 40年代)
\end{tabular} \\
\hline 13 & $\begin{array}{l}\text { ポイント・バーの発達, 中州の発達 } \\
\text { 支川扇状地の延伸 }\end{array}$ & わん曲流の変形 土砂と流量の多い支川合流 & \begin{tabular}{|l|} 
メグナ川 \\
御栜使川
\end{tabular} \\
\hline
\end{tabular}

ている. 特に松浦川のように, 流出土砂量の少ない, 比 較的安定した河道では，洪水による河床変動はわずかで あるので, いったんみおが形成されると，徐々に，しか し確実にある一定限度までのみおの発達がある.このよ うな場合，左右岸のみおの河床高は一般に同じではない ので, 勾配が大きい河川等で, 河床材料の分級作用が大 きく, さらに流路幅が大きい場合には顕著なクランクフ ローが生じることもありうる. 写真に見られるように河 道の中央部に植生が繁茂し, 高木に生育するとみおの鮮 明化が促進され，オリジナル河道とは異なった 河道となる傾向が見られる.

なお，クランクフローの発達の原因には表-1 に示すように種々のものが存在するが縦断勾配 の急変点, 大きな支川の合流点, 水路幅の急変点, 著しい湾曲部等においては土砂の条件によって は, クランクフローが急激に発達することもあ る. クランクフローが急激に発達した事例とし て, 勾配急変の典型例は常願寺川であろう.こ れは, 旧扇状地の上に近年の武山の崩壊による 土砂婎積があって縦断的にみるとまさに一点で 勾配が変化している場合である. 昭和 40 年代の 洪水において流量が十分に減少した $200 \mathrm{~m}^{3} / \mathrm{s}$ か らの 減水過程で左岸側に砂の堆積が始まり, 一 夜にして大きな砂州に成長し，これを迂回する 左岸から右岸へ向うクランクフローによって高 水敷が約 $70 \mathrm{~m}$ の侵食をうけた事例がある. 流路 幅が広いだけに左右岸の高低差によっては著し い鋭角水衝流となったためと判断される. 多摩 川狛江地区の宿河原堰に関連する左岸側の高水 敷及び河道侵食の迁回流も記憶に新しい.これ
は堰の上流側に存在した堰に接続する高水敷端の旧堤が 破堤し, 鋭角水衝流がいっきに発達した例である. これ と似た現象には, 多摩川の他の堰及び菊池川等, 多くの 事例がある. その他, 流出土砂量の多い支川合流があつ て, 本川河岸に水衝作用を及ぼす例(典型例は釜無川支川 の御勅使川等), 河口砂州が汀線方向に河口を塞ぐかたち で延伸し，特に退潮時に勢力の大きい鋭角水衝流となる 例, あるいは湾曲流が極端に発達して水衝作用の大きい 流れとなる例など多様なものが存在する.

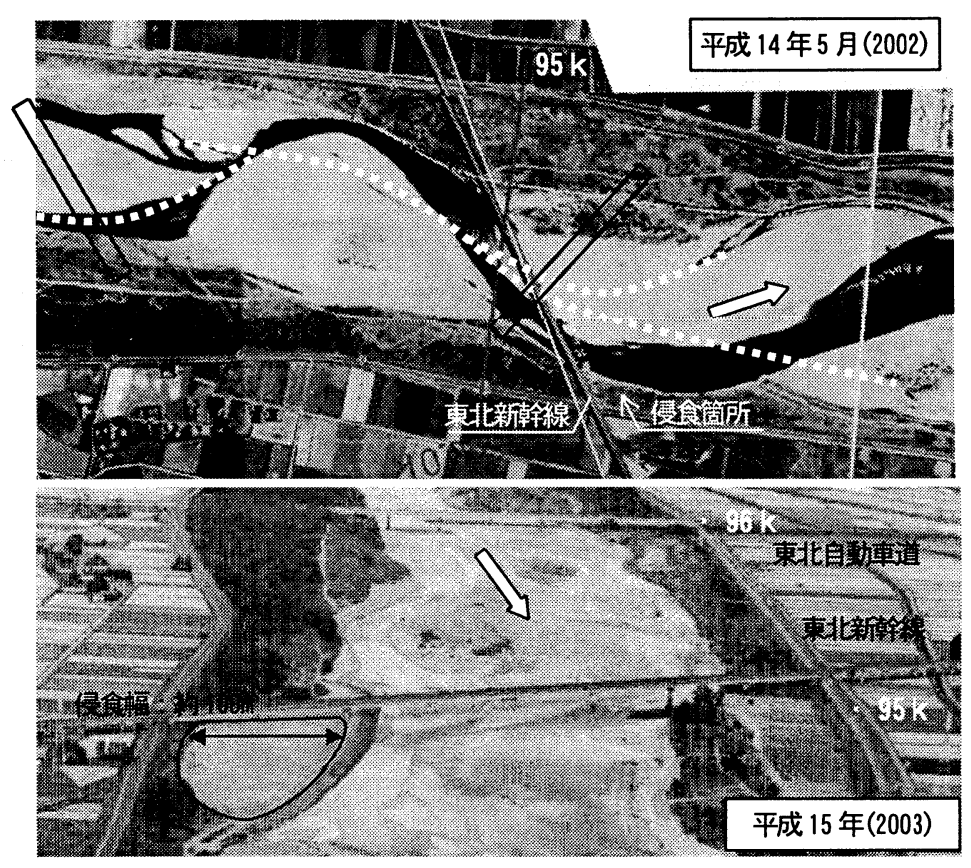

写真-3 鬼怒川におけるクランクフローの発達(上)を示す航空写真と河岸侵 食及びその復旧後(下)を示す斜め写真（写真上には点線で平成 11 年のみお, 及び堤内地情報から推定される大磷堆の位置を 2 ヶ所示している.） 


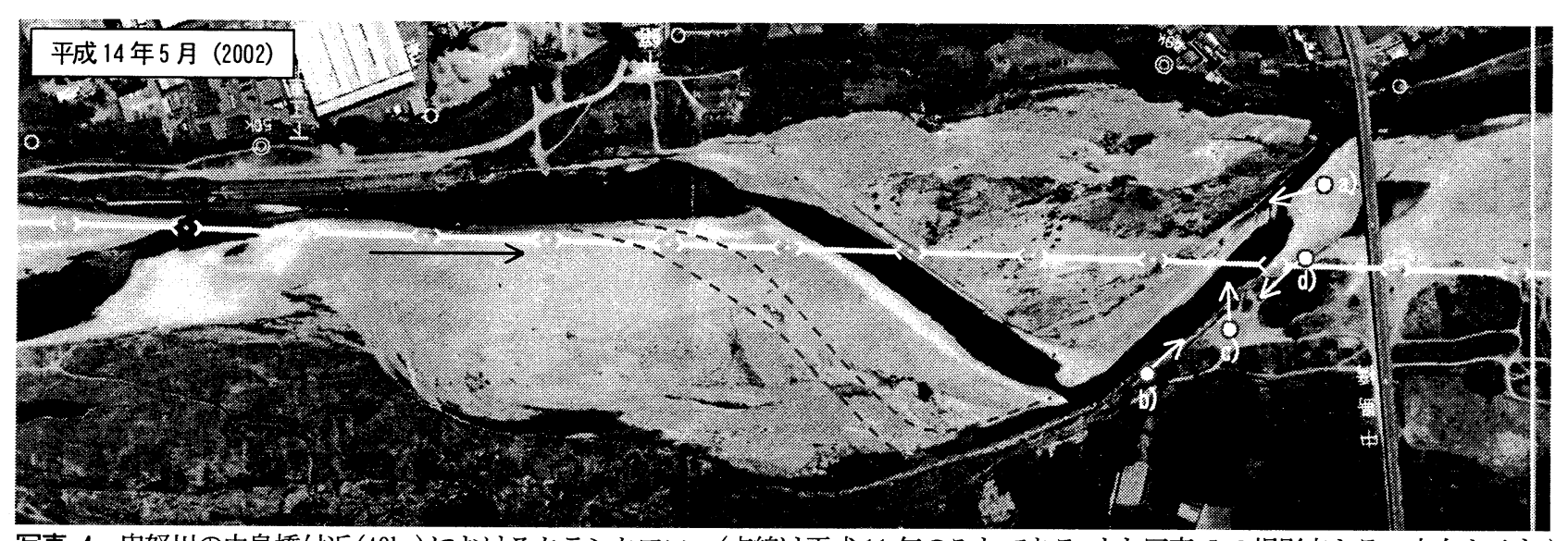

写真-4 鬼怒川の中島橋付近 $(49 \mathrm{~km})$ におけるクランクフロー(点線は平成 11 年のみおである. また写真 -5 の撮影点とその方向を示す.)

\section{3. 発散・収束河道におけるクランクフロー}

以上のような多種多様なクランクフローと鋭角水衝流 のなかで, 一般的な発達過程を考察する一助とするため, 極端な例として発散·収束河道をとりあげ, 鬼怒川におい て現地調査を行った.

発散·収束河道の蛇行形態は, 大砂を多く含む混合粒径 材料が洪水流による分級作用によって形成される大碑堆 が核となって発達する河道システム 1 である. これは, 玉 石や巨石等の大磁が多く存在する河道においてみられ， 例えば鬼怒川・渡良瀬川・多摩川・神通川などの当該区 間の直上流部において大礫の供給源が存在し, 土砂量と しては比較的少ない河道区間がこれに該当する.

写真-3 で 2002 年の蛇行流の状况は鬼怒川 $95 \mathrm{~km}$ 付近を 斜めに渡河する新幹線橋梁の直上流部をこれと平行する かたちで，形成された左岸から右岸に向う鋭角水衝流の 様子を示す. 写真-3 の 2003 年の状况は 2003 年の出水 (ピ 一ク流量約 $3000 \mathrm{~m}^{3} / \mathrm{s}$ 程度) の後に侵食された河岸を約 100 $\mathrm{m}$ 埋戻して実施した災害復旧工事の施工後の様子を示す 上空からの斜め写真である. なお, 写真のみおの位置は 工事に伴い若干の変更が行われている. この場合, 右岸 沿いのみおの延伸に伴う左岸側上流の鋭角水衝流の発達 が先であり, 河岸侵食に伴うみおの発達と下流側への延 伸があったが，橋梁下流部左岸側に存在する強固な砂州 に阻まれ，左岸側から右岸側に向う規模の大きな鋭角水 衝流へと変化した. そのため, このクランクフローの角 度が鋭角となるに従い，流れの勾配は増大し，鋭角水衝 流の侵食力の増大があった. 右岸側の河岸は玉石·砂利. 砂の構成材料で耐侵食性は大きくないので, 侵食速度は 今後の問題であるが, 堤防が危険視されるほどの侵食と なった.

次の写真-4 は鬼怒川の $49 \mathrm{~km}$ 地点で中島橋下流を収束 点とする上流側の発散面上における被災直前のクランク フローの様子を示す.この付近では, 勾配が緥断的に変 化しつつあり, 礫の含有率が減少し, 反対に砂の含有率 が多くなっている. この災害をもたらしたクランクフロ

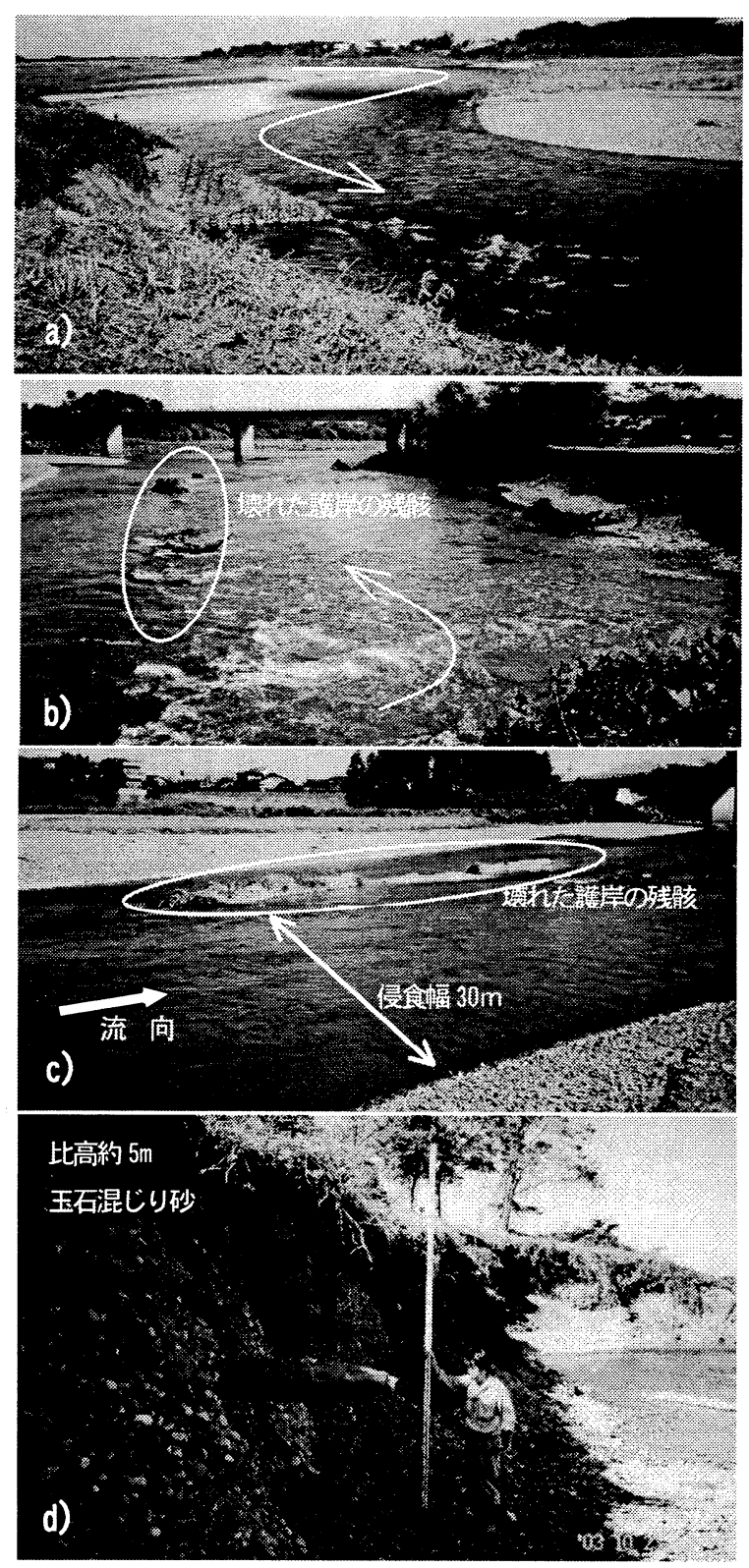

写真-5 鬼怒川の中島橋付近 $(49 \mathrm{~km})$ におけるクランク

フローによる河岸侵食状況と河岸構成材料 (平成 15 年)

一の発達の原因は, 左岸沿いのみおが下流に延伸し, 写真 -4 に示しように平成 11 年の鋭角水衝流が下流に平行移 


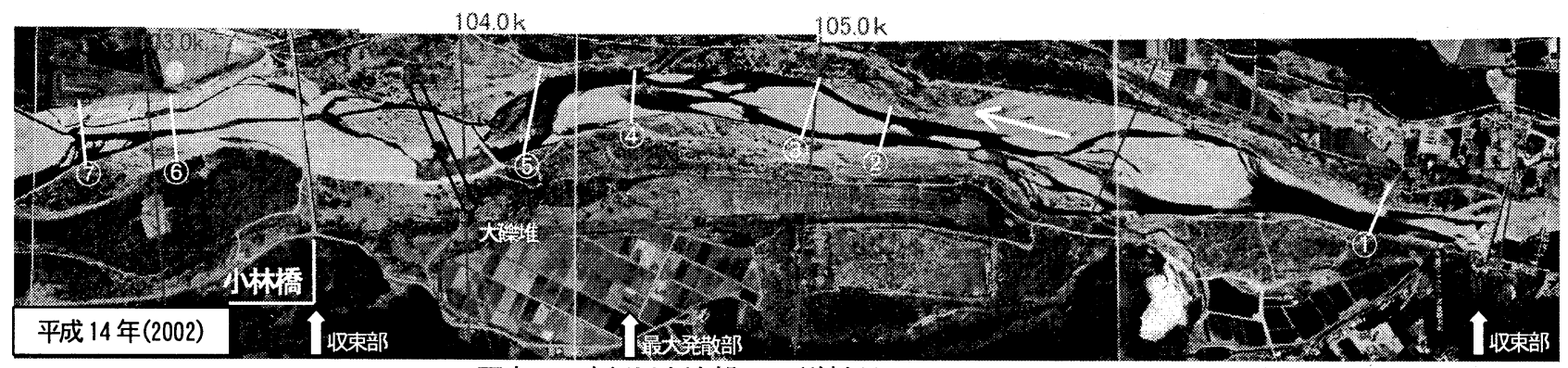

写真-6 鬼怒川上流部の 2 列蛇行とクランクフロー

(図に示す発散·収束の位置は昭和 22 年時当時の位置を示し，基幹大礫堆の位置は堤内地情報から推定される位置を示している）

動したが, そのため右岸側における鋭角水衝流の角度 が $130^{\circ}$ から $110^{\circ}$ になったことによるものと考えら れる. 写真-5a)は 2003 年の出水後のクランクフローで

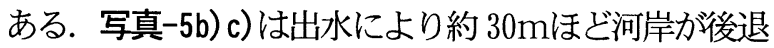
し, 被災前の低水護岸が被災後の低水流路の中央部に 残っている様子を示している. 写真-5d) は大きく侵食 を受けた護岸の粒度構成ならびに比高を示している.

ここで, 鬼怒川河道に関する現地調査に基づいてク ランクフローの関連事項について述べる. 写真-6に示 す航空写真において，小林橋 $(103.5 \mathrm{~km})$ の直上流部に は, 安定した大碟堆が存在し, その上流側には発散面 が発達している. 一般に発散面はカマボコ型形状とな っており, 中央で高く, 左右岸で標高が低くなってい る. いくつかの横断形状を図-1に示す. 図における各 番号の位置は写真-6 の番号に対応している. (1)は収束 部下流に位置し, 安定した溝型断面となっている. (2) は発散面の始端であり, カマボコ断面への移行過程に ある. (3)は発達したカマボコ型河道となっている. 一 般に縦断的に見て流水幅が狭い方が水深は大きいと考 えてよい. (4)も 2 列蛇行区間である. この時点で左岸 側に流水はないが河床高は低くなっている. それが後 で述べる(5)のクランクフローに関係している. 小林橋 上流に大磁堆が存在するのでその下流部は収束部とな っている. (6)は発散面の上流部であり，(7)に至るとか なり発達している. 鬼怒川ではこのような発散・収束が 大礫堆をかいしてシステム的に繰り返されている. 次 に河床材料については，一般にその粒径は中央部で大 きく, 左右岸では相対的に小さい. その後, 発散面に おいて堤防が建設された場合には，特に堤防前面で低 く, 流れが寄ってみおとなる. 基本的には 2 列蛇行で ある. 両岸のみおの高さは必ずしも同じではなく, ま た低い方に流水が存在するとは限らない。これはクラ ンクフローにとっては, 重要事項である.

前述のように, 小林橋上流発散面内で, $105 \mathrm{~km}$ 付近の 河道は有堤部で, 典型的な力マボコ形状を呈している. この付近の平均的な河床縦断勾配は $1 / 250$ 程度であるが， カマボコ断面の背を連ねる勾配は小さく，場合によって は下流の方が高い逆勾配になることもある.この背を連 ねるあたりの河床材料には大礫が多く，これは大洪水時 におけるピーク流量付近の洪水流の直線的な流れによっ

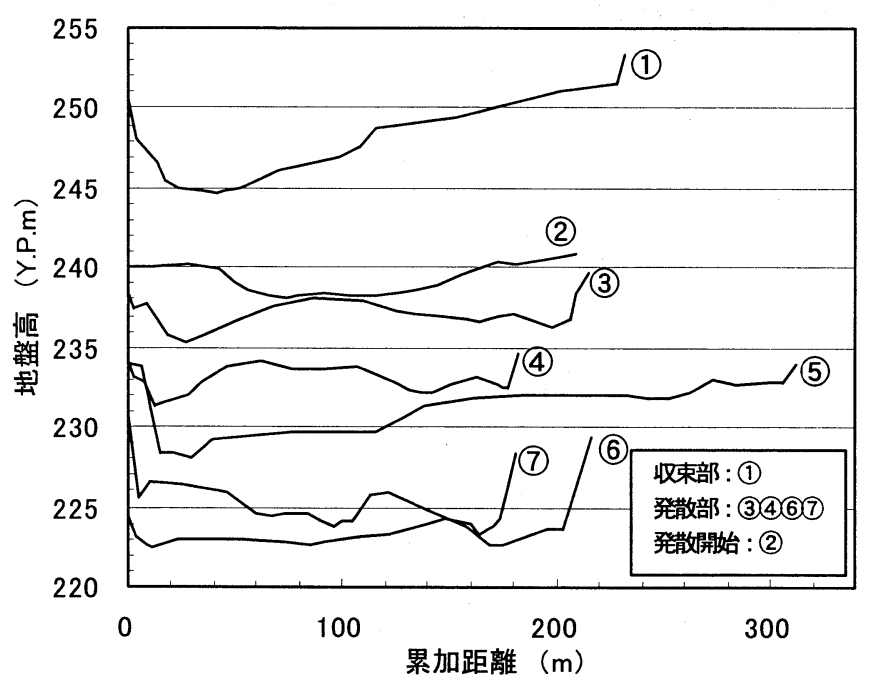

図-1 鬼怒川における横断形の例(写真-6 参照)
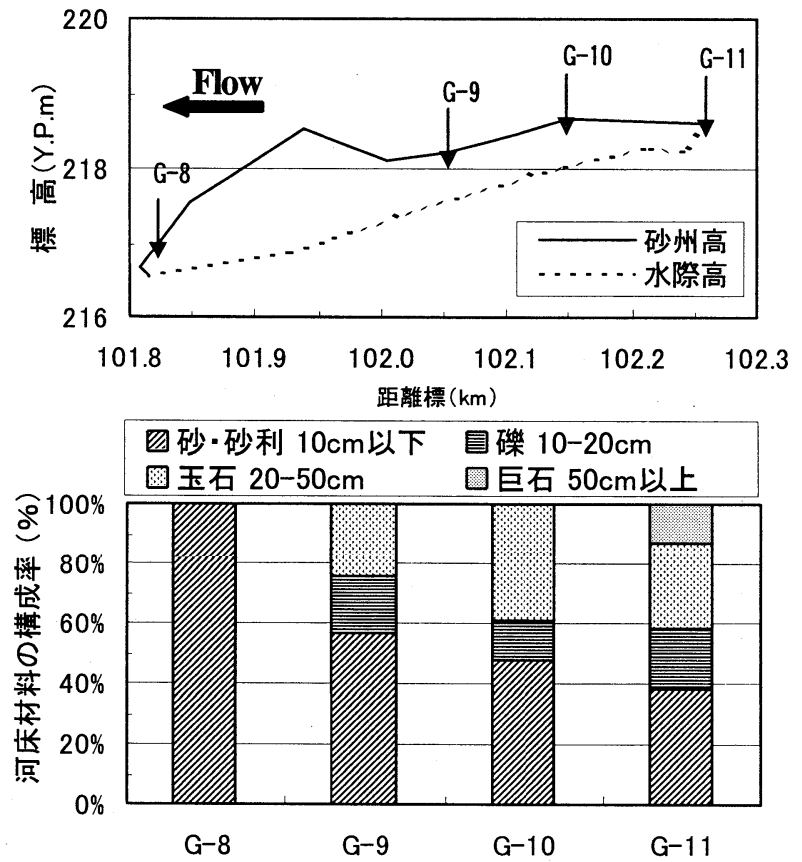

図-2 筋状大礫堆の縦断形及び可床材料の構成率 て輸送され堆積したものと推定される. 少し下流の例で あるが, $102 \mathrm{~km}$ 付近では, 図-2 に示すように，水際線よ り上部の比高が $2 \mathrm{~m}$ 以上となっている. この背の部分に大 礫が集中しており,筋状の大礫堆の様相を呈している.こ の筋状大礫堆の長さは有限であり，下流側は急勾配で落 ちこんでいる. また，笳状大碟堆の粒度構成は図-2 に示 すようである．筋状大礫堆の上流部では巨石や玉石の構 


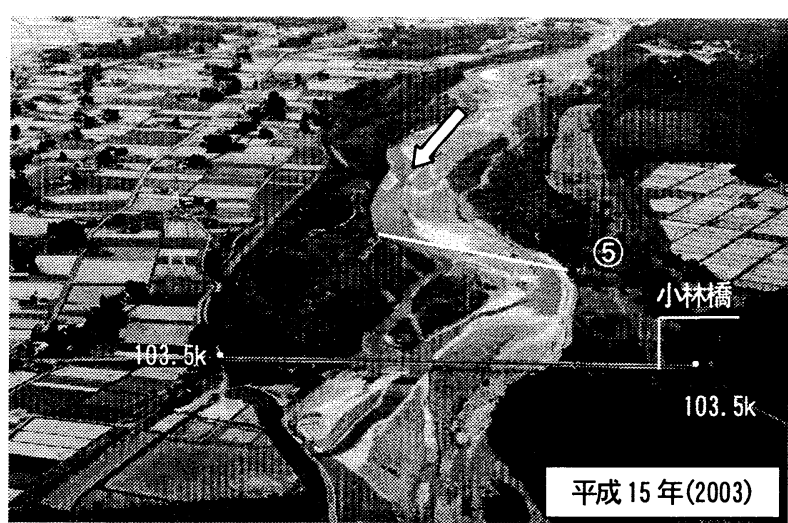

写真-7 鬼怒川の小林地区におけるクランクフロー

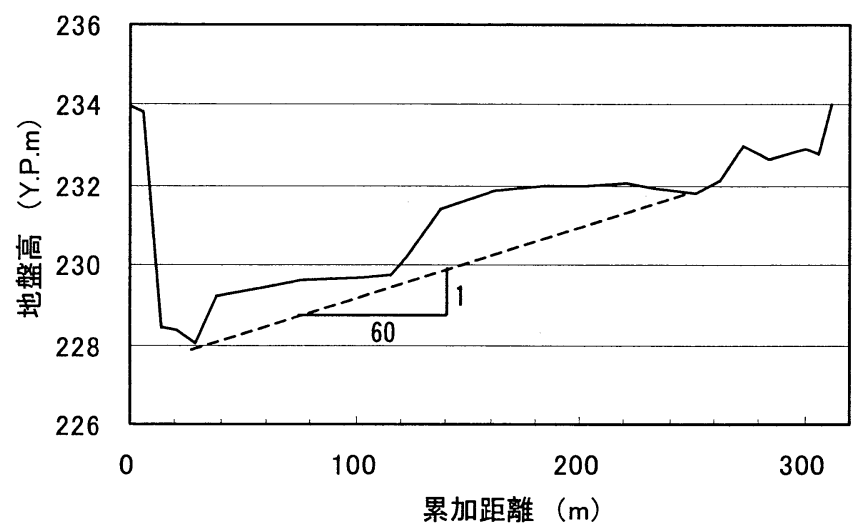

図-3 クランクフローの鋭角水衝流の 流れ方向の河床地形(5)断面)

成比率が大きく，これは上流ほど大きい，一方，砂や砂 利は上流部ほど少なく下流ほど多く，下流端において急 増している. 大礫は洪水中の流量が大きい期間に生じる 比較的直線的な主流線沿いに輸送され堆積したものと判 断される.そのような傾向は，いずれの筋状大礫堆におい ても見ることができる. クランクフローは，例えばこの ような筋状大礫堆の終点切れ目のような所で河道を横断 している. $105 \mathrm{~km}$ 付近では, 左岸側に対し $70 \mathrm{~cm}$ ぼ高い 低水流が右岸側に存在する．この流れはときに筋状大碰 堆の切れ目で横断することがある. しかし，この場合 104. $3 \mathrm{~km}$ 付近に次の筋状大礫堆が存在し, また直線的な護 岸の存在によりさらに引き続いて右岸側を流下している。 その結果, $104.2 \mathrm{~km}$ 地点に至って, 右岸側の大きな砂州の 存在でみおの延伸が抑えられ，強制的に変更させられる かたちで右岸から左岸への横断流が発達した. 鋭角水衝 流の成長である.これがまた左岸側における護岸建設の 原因となっている. このクランクフローについて地形を 調べてみると図-3のようであり, 鋭角水衝流の長さ $250 \mathrm{~m}$, 高低差 $4 \mathrm{~m}$, 平均勾配 $1 / 60$ である. 後述のなお書きの条 件から例えば, 水深が $2 \mathrm{~m}$ のとき, 粗度係数 $\mathrm{n}=0.035$ 程 度とすると, 流速は $6 \mathrm{~m} / \mathrm{s}$ ほどになる. 局所的に落込部 だけをとりあげると $1 / 40$ 程度の勾配となり，流速はさら に大きい鋭角水衡流となる. 写真-7 に発達したクランク フロー(5)を示す．現在，左岸側の鋭角水衝流下流には小 林橋までの護岸が建設された. ただし，写真では工事中 の瀬替え水路が見えており，現段階では左岸護岸沿いの
みおは未発達である.

なお, 鬼怒川は昭和 22 年の航空写真の形状が基本的に は現在も維持されている安定した河道を有している. 従 って, 数回の大洪水の河床変動に与える影響は顕著では ない．洪水中にクランクフローが明膫になるのは高い砂 州が水面上に現れてからであり, 減水過程に注目すべき である。

\section{4. 結 論}

クランクフローは那賀川において最初に認識されたが, 以降あまり注目されることはなかった．ところが，災害 が発生するたびごとに，旧河川法に基づく計画断面の維 持を目標として，主として，定められた技術基準に基づ いて, なかば機械的に護岸・根固の対応策が実施されるの が一般的であるといえよう.この場合,護岸沿いの流れが 鮮明化し, 延長されることがあれば, クランクフローに発 達する可能性がある. そのため, クランクフローは拡大 の方向に推移し問題が顕在化しているとみなされる.

本論では, クランクフローを定義し，鋭角水衝流と河 岸侵食を考慮の上，クランクフローの分類とそれぞれの 原因について通覧し，侵食現象の規模について既往資料 の整理を行い，最初の試みとて総括的なとりまとめを行 った.

今後は河川改修や河川維持, 及び被災対応策において, 河道の蛇行形態のシステムにクランクフローや鋭角水衝 流に対する配慮を行って対処しなければならない。護岸・ 根固工には水制工などが検討対象となるであろう.

なお，クランクフローに関する本格的詳細な内容につ いては今後の研究結果に期待しなければならないが，砂 利まじり等で侵食を受けやすい河岸を有する河道の場合 で，例えば発散面のカマボコ型河道のように流路幅が広 く，横断方向に勾配が大きく著しい鋭角水衡流の発達が 予想される河川では緊急課題として従前の対策工法の見 直しが必要と考えられる.

本研究では, ニーズに応じてクランクフローの基本的 事項について考察を行い，今後の研究の発展性と方向性 とを示唆しえたものと考える.

\section{参考文献}

1）須賀如川:大磁を含む混合粒径河川における河道システムの 本質に関する考察, 河川技術論文集, VOL. 10, pp95〜100.

2）井口章平：川を見る, p. 74，東大出版会, 1979.

3）三品智和，須賀如川，他 5 名: 余笹川の災害対策後河道の河 道特性に関する考察, 水工学論文集, 第 46 巻, pp343 348, 2002.

4）三品智和，須賀如川，助川純一郎，古川保明 : 谷底冲積地の 自由蛇行河川における護岸・根固の現地調査之二.三の考察, 河川技術論文集，VOL. 9，pp131～136，2003.

(2004.9. 30 受付) 